К. ЛЭЭТС, Т. КААЛ,

Малле ШМИДТ, К. КУДРЯВЦЕВА

\title{
ВЛИЯНИЕ ПРИРОДЫ КАТАЛИЗАТОРА НА ТЕЛОМЕРИЗАЦИЮ ИЗОПРЕНА С $\alpha$-ХЛОРМЕТИЛИЗОПРОПИЛОВЫМ ЭФИРОМ
}

K. LAATS, T. KAAL, Malle SCHMIDT, K. KUDRJAVTSEVA. KATALUSAATORI MOJU ISOPREENI JA $\alpha$-KLOORMETOOLISOPROPOOLEETRI TELOMERISATSIOONILE

K. LAATS, T. KAAL, Malle SCHMIDT, K. KUDRYAVTSEVA. THE INFLUENCE OF THE NATURE OF CATALYST ON TELOMERIZATION OF ISOPRENE WITH $\alpha$-CHLORMETHYLISOPROPYLETHER

Состав продукта теломеризации изопрена с $\alpha$-хлорметилизопропиловым эфиром в присутствии $\mathrm{ZnCl}_{2}$ (в качестве катализатора) приведен нами ранее [']. Образующийся теломер состоит в основном из моноаддукта 1-хлор-3-метил-5-изопропокси-2-пентена, который представляет собой продукт 1,4-присоединения хлорэфира к изопрену. Последний, по данным ГЖХ и ЯМР-спектров, состоит из смеси $E$ - и $Z$-изомеров, которые выделены нами в чистом виде с помощью препаративной ГЖХ.

В настоящей работе исследовалось влияние природы катализатора на протекание реакции теломеризации. Результаты, полученные в присутствии разных катализаторов, приведены в таблице.

Теломеризация изопрена с $\alpha$-хлорметилизопропиловым эфиром в присутствии разных катализаторов

\begin{tabular}{|c|c|c|c|c|c|c|c|c|c|c|}
\hline \multirow{3}{*}{ Катализатор } & \multirow{3}{*}{ 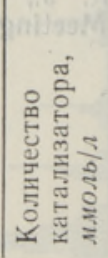 } & \multirow{3}{*}{ 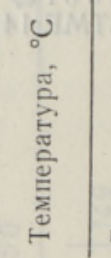 } & \multirow{3}{*}{ 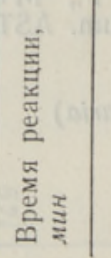 } & \multirow{3}{*}{ 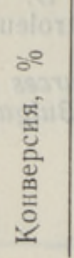 } & \multirow{3}{*}{ 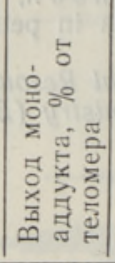 } & \multirow{3}{*}{ 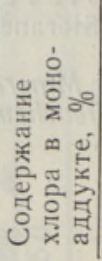 } & \multirow{3}{*}{ 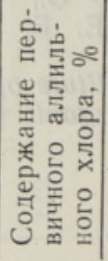 } & \multicolumn{3}{|c|}{$\begin{array}{l}\text { Содержание изо- } \\
\text { мерных хлоридов в } \\
\text { моноаддукте, \% }\end{array}$} \\
\hline & & & & & & & & \multicolumn{2}{|c|}{ первичных } & \multirow[b]{2}{*}{$\begin{array}{l}\text { третич. } \\
\text { ного }\end{array}$} \\
\hline & & & & & & & & $Z$ & $E$ & \\
\hline $\mathrm{ZnCl}_{2}$ & 18, & & 240 & 62,4 & 88,0 & 19,6 & 17,9 & 30,8 & 56,0 & 6,5 \\
\hline $\begin{array}{c}\mathrm{SnCl}_{4} \text { (раствор в } \\
\text { дихлорэтане) }\end{array}$ & 0,22 & $40-21$ & 103 & 59,4 & 83,4 & 20,1 & 17,5 & 23,6 & 63,0 & 8,1 \\
\hline То же & 1,1 & $45-22$ & 12 & 64,1 & 71,0 & 20,4 & 17,4 & 36,2 & 49,2 & 6,6 \\
\hline $\begin{array}{l}\mathrm{Snl}_{2} \cdot 2 \mathrm{H}_{2} \mathrm{O} \text { (раст- } \\
\text { вор в эфире) }\end{array}$ & 0,18 & $30-22$ & 100 & 56,4 & 83,5 & 20,1 & 15,3 & 17,5 & 59,0 & 19,7 \\
\hline $\mathrm{BiCl}_{3}$ & $31,8^{*}$ & $28-21$ & 1200 & 70,6 & 74,0 & 20,2 & 17,3 & 31,4 & 53,0 & 5,1 \\
\hline $\mathrm{FeCl}_{3}$ & $30,8^{*}$ & $52-22$ & 70 & 55,9 & 37,4 & 20,0 & 18,0 & 23,0 & 52,0 & 9,2 \\
\hline
\end{tabular}

* Қатализатор нерастворимый, 
Наилучший выход моноаддукта ( $88 \%$ от общего количества теломера) достигнут при применении $\mathrm{ZnCl}_{2}$. Почти такие же результаты получены в присутствии $\mathrm{SnCl}_{4}(0,22$ ммоль/л). Повышение концентрации последнего до 1,1 ммоль/л снижало выход моноаддукта от 83 до $71 \%$. Изменялось также содержание $E$ - и $Z$-изомеров в нем. Высокий выход моноаддукта получен также в присутствии $\mathrm{SnCl}_{2} \cdot 2 \mathrm{H}_{2} \mathrm{O}$. В отличие от продуктов, полученных в присутствии других катализаторов, в этом продукте содержится $19,7 \%$ третичного хлорида - продукта 1,2 -присоединения хлорэфира к изопрену. В присутствии $\mathrm{BiCl}_{3}$ реакция идет медленно. Повышение температуры реакционной смеси отмечено приблизительно через 0,5 ч после прибавления катализатора. Состав моноаддукта примерно такой же, как при применении $\mathrm{ZnCl}_{2}$, но выход его ниже. Очень энергично идет реакция с $\mathrm{FeCl}_{3}$, однако выход моноаддукта намного ниже, чем при применении других катализаторов. В реакции теломеризации изопрена с его гидрохлоридами в присутствии этого катализатора наблюдалось также образование большого количества высших теломеров $\left[{ }^{2}\right]$.

Сделана попытка провести теломеризацию в присутствии $\mathrm{CdCl}_{2}$. При перегонке реакционной смеси теломер не получен.

Во всех опытах, приведенных в таблице, в качестве растворителя использовался $\boldsymbol{\mu}$-гексан. Испытывались также эфир, бензол, четыреххлористый углерод и ацетон (катализатор $\mathrm{SnCl}_{4}$ ). Во всех растворителях, кроме ацетона, конверсия была почти одинаковой $-71-75 \%$ (за 24 ч). В ацетоне конверсия составляла $20,6 \%$ и выход моноаддукта $44 \%$. Состав последнего во всех случаях был практически одинаков.

\section{Выводы}

Природа катализатора мало влияет на состав продуктов теломеризации. Исключение составляет катализатор высокой активности $\mathrm{FeCl}_{3}$, в присутствии которого преобладает реакция роста цепи (выход моноаддукта мал). В присутствии катализатора средней активности $\mathrm{SnCl}_{2} \cdot 2 \mathrm{H}_{2} \mathrm{O}$ увеличивается выход третичного изомера моноаддукта за счет уменьшения количества $Z$-изомера.

\section{Экспериментальная часть}

$\alpha$-Хлорметилизопропиловый эфир получен по методике $\left[{ }^{3}\right]$ с выходом $58 \%$, т. кип. $98-105^{\circ} \mathrm{C}, d_{!}^{20} 0,9790, n_{D}^{20} 1,4080$. Найдено, \%: Cl 31,3. Вычислено, \%: $\mathrm{Cl} 32,6$. Изопрен и растворители - гексан и бензол - обезвоживались кипячением над металлическим натрием с последующей перегонкой. Эфир и $\mathrm{CCl}_{4}$ сушили $\mathrm{P}_{2} \mathrm{O}_{5}$ и перегоняли.

В трехгорлую колбу $(0,5 \Omega)$, снабженную мешалкой, холодильником с хлоркальциевой трубкой и термометром, загружали 25 мл (0,225 моль) хлорэфира, 25 мл $(0,25$ моль) изопрена и 50 мл растворителя. При охлаждении водой и перемешивании добавляли катализатор. Продукт реакции промывали водой для извлечения катализатора и высушивали на $\mathrm{CaCl}_{2}$. Растворитель отгоняли и остаток перегоняли в вакууме. Т. кип. $65-75^{\circ}$ (5 м.м).

Третичный хлорид 3-хлор-3-метил-5-изопропокси-1-пентен идентифицирован с помощью ГЖХ по эталону, полученному из 3-метил-5-изопропокси-1-пентен-3-ола ['] с $\mathrm{PCl}_{2}$. В продукте обнаружен также первичный хлорид, образующийся в результате аллильной перегруппировки. 
Продукты теломеризации анализировались в приведенных ранее условиях [']. Времена удерживания 3-хлор-3-метил-5-изопропокси-1-пентена, $Z$ - и $E$-1-хлор-3-метил5-изопропокси-2-пентена равны соответственно 1,00, 2,14 и 2,74 .

\section{ЛИТ Е РАТ У РА}

1. Каал Т. А., Эрм А. Ю., Линдс а ар А. У., Кальюранд М. Р., Лээтс К. В. О составе продукта теломеризации изопрена с $\alpha$-хлорметилизопропиловым эфиром. - ЖОрХ, 1975 , т. 11 , вып. 9, с. $1809-1810$.

2. Лээтс К. В., Мукс Э. А. О влиянии природы катализатора на состав продуктов и кинетику теломеризации. - ЖОрХ, 1974, т. 10, вып. 9, с. 1857-1860.

3. Пок он о в а Ю. В. Галоидэфиры. М.-Л., 1966, с. 82.

Ннститут химии

Академии наук Эстонской ССР
Поступила в редакцию $7 /$ II 1980 